\title{
Moral categories in the financial crisis
}

\author{
Marion Fourcade*, Philippe Steiner, Wolfgang Streeck \\ and Cornelia Woll
}

*Correspondence: fourcade@berkeley.edu

Karl Marx observed long ago that all economic struggles invite moral struggles, or masquerade as such. The reverse may be true, too: deep moral-political conflicts may be waged through the manipulation of economic resources and the design of policy devices. Using the recent financial and Eurozone crises as empirical backgrounds, the short papers presented here by Philippe Steiner, Cornelia Woll, Wolfgang Streeck and Marion Fourcade propose four different perspectives on the play of moral judgments in the economy and call for a broader and more systematic scholarly engagement with this issue. Focusing on executive compensation, bank bailouts and the sovereign debt crisis, the discussion forum builds on a roundtable discussion held at the opening of the Max Planck Sciences Po Center on Coping with Instability in Market Societies (MaxPo) in Paris on November 29, 2012.

Keywords: financial crisis, ethics, inequality, moral norms, political economy, debt JEL classification: A13 relation of economics to social values, G01 financial crises, G10 general financial markets, Z13 economic sociology

\section{Introduction}

\section{Marion Fourcade ${ }^{1}$ and Cornelia Woll ${ }^{2}$}

${ }^{1}$ University of California, Berkeley, CA, USA; Sciences Po, Max Planck-Sciences Po Center on Coping with Instability in Market Societies (MaxPo), Paris, France;

${ }^{2}$ Sciences Po, Max Planck Sciences Po Center on Coping with Instability in Market Societies (MaxPo), Paris, France

The collapse of the investment bank Lehman Brothers on September 9, 2008 opened the black box of modern financial markets to the world. It exposed finance's vast and complex machine, until then largely invisible to the wider public and 
poorly mastered by even its most skilled practitioners. With that, the technical became political. Esoteric terms such as collateralized debt obligations, credit default swaps, haircuts, yield spreads and write-downs were catapulted to public fame. The obliviousness of regulatory institutions became a topic for dinner conversations.

The new forms of scrutiny also exposed finance as a social activity subject to considerable dishonesty and recklessness. Expert reflections about executive pay, bank rescues or sovereign debt default were laden with statements about good and bad incentives, moral hazard and loopholes. The public responded with categorical distinctions between the ruthless and the clueless, the corrupt and the honest, the lazy and the industrious, the profligate and the frugal, the greedy and the rest, what is right and what is not. Vindicating Marx's statement in the Economic and Philosophical Manuscripts of 1844 that '[political economy] is-for all its worldly and debauched appearance-a truly moral science, the most moral science of all' (2005, p. 361), such arguments continue to saturate specialist debates and political negotiations about the most appropriate responses to the banking and sovereign debt crises. Are financial executives really worthy of the outsized compensations they have enjoyed so far, or do enormous bonuses offend common decency (Steiner, 2012)? Is there a just interest rate and is it ethical to protect the right of creditors to receive interest payments? Should some lending practices be described as predatory, and made illegal? Is it morally acceptable to bail out imprudent financial institutions using taxpayers' money, when imprudent individual borrowers are left struggling? People's sense of justice may be seriously hurt, as Swedberg (2013) points out. Is it fair to protect the holdings of foreign creditors (e.g. German and French banks, for the most part) while citizens suffer to repay? Does Greece deserve to be saved, given its government's lies about the true state of its national debt? Does the fact that Cyprus is a money-laundering platform justify a harsher treatment of the population that supported, implicitly or explicitly, the island's conversion into a fiscal paradise? Is it right that the European Central Bank — an unelected body-drastically varies its assistance to Italy depending on the government in power there?

Competing visions of fairness, moral tolerability, right and wrong courses of action are written all over economic struggles. Ordinary attitudes about the economy - for instance, about the 'market', or about poverty-mobilize socially and historically situated conceptions of justice or human nature, sometimes explicitly couched in religious or political terms (Steensland, 2010; Steensland and Schrank, 2011). To the extent that they are gendered beings with a distinctive history, a social position, a nationality, social scientists are not immune from these collective forces (Bourdieu, 1988). Notwithstanding the externality cherished by experts, policy struggles (including what to investigate, and how; or the criteria by which to evaluate policy options) always imply political choices — that is, choices about the distribution of economic power in society. Thus some scholars (Lebaron, 2000; Nelson, 2001) have described economics, or its different intellectual currents 
(Keynesian, Chicagoan, Marxist, etc.), as belief systems. As Alan Wolfe (1989, p. 6) put it, 'even those social sciences that pride themselves on rigorous value neutrality, insisting that they are only describing how people do act, not advocating how they should, contain implicit (and often explicit) statements of what people's obligations to one another should be.' But the point is not merely about the scholastic biases of different disciplines. It is much broader. Economies are shaped by the moral dispositions and beliefs of the individuals who govern them as much as they are governed through techniques and numbers (Lascoumes and Le Galès, 2005). These dispositions, in turn, stem in part from a symbolic metamorphosis of political and economic interests, both individual and collective.

The current financial and economic crisis in Western economies offers many empirical sites for sharpening our theoretical frameworks in this direction. If this short symposium offers a programmatic call to recognize the relevance of moral judgments when analyzing economic processes, its more immediate objective is to analyze different ways in which moral categories have been mobilized in the financial and Eurozone crises. We begin at the micro-level, with individuals, and scale up gradually, toward organizations, specific countries and interstate relations.

In the first piece, Philippe Steiner analyzes the reconfiguration of the 'moral economy' surrounding income inequalities in light of repeated revelations of outlandish executive pay in the French media and the consciousness-raising activities of the so-called 99\%. These events, Steiner suggests, have prompted a better grasp of the reality of income inequality (people continue to vastly underestimate the income of a CEO, but less than they used to). But-and perhaps paradoxically, given the public outrage over these issues-their tolerance for income inequality has increased, too (in France, the desired inequality ratio between a worker's wage and a CEO's has jumped from 6.3 in 1999 to 18 in 2010).

Next, Cornelia Woll's analysis of bank bailouts underlines the dilemma between the collective problem of systemic risk and the individual one of moral hazard. None of the solutions adopted to face the crisis has been able to solve both problems at once, she argues; to avoid systemic risk, governments have committed large amounts of public money to save the culprits of the financial mess, increasing the moral hazard problem. Woll argues that we need to enhance the collective moral responsibility of the financial industry so that banks will be able to cooperate among themselves and participate in their own rescue as a group.

In the subsequent piece, Wolfgang Streeck offers a powerful indictment of the European Commission and financial elites in his interpretation of the unfolding of the Greek economic tragedy. European institutions actively encouraged the Greek credit binge, Streeck argues, first on the supply side (by lowering fiscal transfers to Greece and turning a blind eye when the country sharply cut its taxes) and then on the demand side, by indicating that Greece's public debt was worth that of any other Eurozone member state (which caused financial markets to rush for Greek bonds). The notion that such irresponsible dealings would have to be erased through the pain 
and suffering of ordinary citizens (who, as democratic voters, are now held responsible for their governments' disastrous choices) is deeply troubling and a warning sign that Europe's economic designs may benefit no one but the most powerful.

Finally, Marion Fourcade examines the cultural and political consequences of the economic morality plays being acted in the corridors of Brussels and Washington. She reminds us that debt, whether contracted interpersonally or at the collective level between formally equal parties, is always a relationship of power, which establishes hierarchies in material resources and moral character. When one party struggles to fulfill its obligations, moral regulation intensifies. She argues that Eurozone troubles are not only contributing to a rapid divergence in economic trajectories between North and South, they are also awakening old civilizational complexes, the cruelty of cultural stigma (as applied to entire populations) and the ghost of Europe's violent past.

All too often, policy-makers and intellectuals delude themselves into believing that moral judgments can be safely separated from 'objective' benchmarks of economic action; all too often, we take as given the idea that profit must be maximized (Beckert, 2006), or that debt must be repaid (Graeber 2011; Streeck, 2013). We fail to recognize that these injunctions, like all economic processes and actions, are the outcome of contingent human struggles. We must recover our ability to see morality at work in economic processes, in other words to better understand the moral and symbolic work that economic instruments and tools perform, and, conversely, the economic work that moral categorizations do. The political fights that have accompanied blame attributions and punishments (or lack thereof) for the crisis, the seemingly irreversible race for economic virtue among governments, the soul-searching of institutions, such as the IMF, caught in their own contradictions and self-doubts are powerful reminders that economic sociology and political economy have a lot to contribute to current economic debates. Showing the political implications of some recent morality plays across a range of domains is the ambition of the symposium, which brings together a roundtable discussion held at the opening of the Max Planck Sciences Po Center on Coping with Instability in Market Societies (MaxPo) in Paris on November 29, 2012.

\section{Acknowledgements}

We are grateful to Gregory Jackson for comments on all the pieces in this discussion forum.

\section{References}

Beckert, J. (2006) 'The Moral Embeddedness of Markets'. In Clary, B. J., Wilfred, D. and Figart, D. M. (eds) Ethics and the Market: Insights from Social Economics, Oxon, UK and New York, NY, Routledge, pp. 11-25. 
Bourdieu, P. (1988) Homo academicus, Stanford, CA, Stanford University Press.

Graeber, D. (2011) Debt: The First 5000 Years, New York, NY, Melville House.

Lascoumes, P. and Le Galès, P. (2005) Gouverner par les instruments, Paris, Les Presses de Sciences Po.

Lebaron, F. (2000) La croyance économique: les économistes entre science et politique, Paris, Seuil.

Marx, K. (2005) Early Writings, London, Penguin.

Nelson, R. H. (2001) Economics as Religion: From Samuelson to Chicago and Beyond, University Park, PA, Penn State Press.

Steensland, B. (2010) 'Moral Classification and Social Policy'. In Hitlin, S. and Vaisey, S. (eds) The Handbook on the Sociology of Morality, New York, NY, Springer, pp. 455-468.

Steensland, B. and Schrank, Z. (2011) 'Is the Market Moral? Protestant Assessments of Market Society', Review of Religious Research, 53, 257-277.

Steiner, P. (2012) Les rémunérations obscènes: Le scandale des hauts revenus en France, Paris, Zones.

Streeck, W. (2013) 'The construction of a moral duty for the Greek people to repay their national debt', Socio-Economic Review, this issue.

Swedberg, R. (2013) 'The Financial Crisis in the U.S. 2008-2009: Losing and Restoring Confidence', Socio-Economic Review, this issue.

Wolfe, A. (1989) Whose Keeper? Social Science and Moral Obligation, Berkeley, CA, University of California Press.

\section{High wages in the financial crisis}

\section{Philippe Steiner ${ }^{*}$}

Université Paris-Sorbonne and Institut universitaire de France, Paris, France

${ }^{*}$ Correspondence: Philippe.Steiner@paris-sorbonne.fr

In this short piece, I will focus on the moral issue raised by the existence and persistence of high levels of remuneration - which President Barak Obama in his 2010 State of the Union Address called 'obscene'-during a period of financial and economic crisis. I do not intend to go beyond a mere description of this moral issue in the French context. ${ }^{1}$

The present crisis is not only a crisis in both 'real' and 'virtual' economies, it is also a crisis in the moral dimension of prevailing economic opinion. This is

\footnotetext{
${ }^{1}$ This piece is based on my last book, Les rémunérations obscènes (Steiner 2011). In that book I traced the moral dimension from a systematic content analysis of Le Monde, a major French national newspaper, and Sud-Ouest, a regional one. Here, I will limit myself to the first newspaper.
} 
particularly salient with regard to the distributional effects of the financialization of companies. Economic analysis argues that whatever happens in the production of goods, the marginal contribution and the marginal remuneration of each participant should be equal. People are paid according to their contribution to production - no matter which way you measure the former, market forces are supposed to match the two faces of the issue. ${ }^{2}$ Huge payments, the argument goes, should not upset anybody, since they are just signaling the high level of contribution made by the fortunate recipient to the production of wealth. If you add to this credo the use of so-called incentive payments, very large compensations are the fuel that is necessary for the realization of these high levels of contribution. One may wonder whether economic science is a hard science, but nobody can cast doubt upon its status as a hard moral discourse when the distribution of wealth is at stake, as John Stuart Mill warned his readers by the middle of the nineteenth century.

This was all wrecked by the financial crash in September 2008.

By mid-September 2008, French newspapers were telling their readers day after day that at the top level of major firms - notably those which belong to the Standard and Poor's 500 or to its French equivalent, the so-called CAC 40-there was a complete decoupling between performance and the size of remuneration packages (wage + bonuses + stock options + perks); this was particularly the case in the financial and banking sectors.

A sociologist interested in the sociology of markets and its moral underpinnings could then profit from the large amount of data offered by daily newspapers, in his effort to understand the moral reaction that later emerged as social movements, such as 'Occupy Wall Street' with its famous motto 'We are the 99\%', or the European-wide movement known as 'Los indignados'.

What picture emerged from reading newspapers between September 2008 and June 2010 ? It can be summarized by three words: disproportion, disconnection and inequality.

Disproportion when George Pébereau, the former CEO of the Compagnie Générale d'Electricité, commenting on the remuneration of managers such as Philippe Jaffré, Antoine Zacharias, Daniel Bernard and Jean-Noel Forgeard, said that 'they have provoked a feeling of revolt among white collar workers, who are incredulous at the unbelievable remuneration earned by top managers. ${ }^{3}$ Disproportion again when a French trader living in London explained that 'None of my mates in Êcole Polytechnique, not even the one who is now the head of a big automobile

\footnotetext{
${ }^{2}$ There is a large literature on the contribution/remuneration dimension of managers' activity since the rise of financial capitalism: see, for example, Lazear and Rosen (1981), Murphy (1999), Bertrand and Mullainathan (2001), Gabaix and Landier (2008).

${ }^{3}$ Le Monde, September 17, 2008, p. 17.
} 
firm, could earn in a few years as much as I did: enough money to buy a flat in the capital city and a house on the seafront. ${ }^{4}$ Disproportion when a paper stated that the CEO of Goldman Sachs earned 53 million dollars and that the total amount of bonuses paid in the City was 21 billion dollars. ${ }^{5}$ More disproportion still when Le Monde picked up from the Frankfurter Allgemeine Zeitung that the six people at of the head of the Porsche automobile firm had received 143 million euros, half of that sum accruing to the CEO, an amount of money that the German newspaper translated into the extravagant hourly rate of 21346 euros, provided that this economic superman worked $70 \mathrm{~h}$ a week, 52 weeks a year. ${ }^{6}$

Disconnection, when Le Monde mentioned that Patricia Russo, CEO of Alcatel, received a golden parachute worth 6 million euros, when over the previous 8 years the firm had lost $95 \%$ of its share value. ${ }^{7}$ Disconnection again when the newspaper told its readers that 40 billion of the 700 billion dollars of the Paulson plan will be used to pay the bonuses of bankers. ${ }^{8}$ More disconnection still when the newspaper publicized the claim made by the former CEO of a large business bank buyout that he deserved a 10 million dollar bonus-13 times his annual remuneration-because it was his prudent management during the recent crisis that had succeeded in reducing losses for the owners. ${ }^{9}$

Inequality when George Pébereau pointed out that wealth inequality was creating a revolutionary situation: 'the discrepancy between wage earners and the small minority of the privileged, sheltered by political powers, is deepening to the point that the situation is now similar to the revolutionary situation in $1789 .{ }^{10}$ Inequality again when a journalist pointed out: 'Whereas the wages of $90 \%$ of the population have increased slowly (4\%) during the last eight years, the mean wage of the top $1 \%$ has benefitted from a $14 \%$ increase. ${ }^{11}$

The situation was thus socially constructed in terms of moral outrage. Suddenly, economic phenomena that had been either taken for granted, or simply neglected, aroused the contempt of journalists and the middle classes. New justifications had to be devised in order to answer those who were infuriated by the decoupling of performances and remuneration, and who claimed that a more equal distribution of

\footnotetext{
${ }^{4}$ Ibid., September 21-22, 2008, p. 10.

${ }^{5}$ Ibid., October 19-20, 2008, p. 9.

${ }^{6}$ Ibid., December 1, 2008, p. 12.

${ }^{7}$ Ibid., September 3, 2008, p. 17.

${ }^{8}$ Ibid., November 6, 2008, p. 19.

${ }^{9}$ Ibid., December 10, 2008, p. 16.

${ }^{10}$ Ibid., September 17, 2008, p. 17.

${ }^{11}$ Ibid., October 25, 2008, p. 2.
} 
Table 1 CEO revenues to unskilled worker revenues ratio

\begin{tabular}{llcccl}
\hline & Germany & USA & Great Britain & France 1999 & France 2010 \\
\hline Perceived ratio & 8 & 12.5 & 12.5 & 16 & 63 \\
Desired ratio & 5 & 5 & 5.6 & 6.3 & 18 \\
\hline
\end{tabular}

Source: Data from International Social Survey Programme (1999) and GEMASS Survey (2010). See also Forsé and Galland (2011, p. 268).

earnings should be established. Market justifications provided by economists or those receiving those obscene levels of remuneration faced a moral outcry, together with moral claims from those suffering from the economic misbehavior of those in receipt of substantial bonuses. As Émile Durkheim wrote one century ago, the 'law of supply and demand' no longer brought into alignment the moral evaluation of the services provided and the remuneration received; and whatever economists might think about it, 'laypeople felt that it was unfair' (Durkheim, 1976, p. 226). The situation was thus typical of what may be called a moral economy, where economic actions and institutions are evaluated according to a moral point of view different from the one explicitly or implicitly embedded in the prevailing economic discourse.

How is this moral economy structured? A brief comparison between two surveys, an older European (ISSP, 1999) one, and a French one from 2 years ago, makes salient four characteristics-see Table 1.

First, the structure of income distribution remains largely unknown to the public. A majority of the people queried believes that this distribution has the shape of a pyramid (a large number of poor forming the base, with a few wealthy people in the upper reaches), when the distribution has in fact the shape of a lozenge.

Second, in all countries, inequalities are considered by the public to be too great, less so in the USA (with $66 \%$ of the respondents agreeing with this statement), and more so in Europe (respectively, 82, 86 and 89\% respectively in Great Britain, France and Spain).

Third, while wages and the hierarchy of wages are well-known at the bottom of the pyramid of the distribution, the remuneration received at the top is grossly underestimated. In 1999, respondents underestimated the ratio between the wage of a worker and the remuneration of a $\mathrm{CEO}$ by a factor 10 ; the underestimation was still of a factor of 5 in 2010.

Fourth, respondents were not egalitarian, since they limited their desired ratio to a reduction of estimated inequalities by a factor 2 (this factor is somewhat larger in France: 3 in 1999 and 3.5 in 2010 as shown in Table 1). Respondents were not stubbornly attached to their previous views on the issue, since French data show how dramatic was the change in the desired ratio, which jumped upward and increased 
the income of a CEO from 6.3 times the unskilled worker's wages to 18 timesabout 22000 euros a month, according to the current minimum wage in France.

These characteristic features of the moral economy, engendered by the existence and persistence of obscene remunerations rewarding failure and cupidity, prompt some concluding comments.

First, inequality does matter, as Joseph Stiglitz (2012) wrote in his last book. It matters because perceived inequality may have far-reaching consequences for the functioning of a democratic society, notably when a large majority of the people have the feeling that they cannot do anything to change the situation. The present low level of confidence in political leaders is (in France-but is this limited to France?) related to what Stiglitz calls the government 'of the $1 \%$, for the $1 \%$, by the 1\%' (Stiglitz, 2012, p. xi and chapter 9). In this sense, the rise of economic inequality which introduces a major cleavage between those who belong to the first percentile of the income distribution and the remainder of society (Piketty and Saez, 2003; Piketty, 2005) can be considered a form of social pollution, downgrading the quality of social life, in the same way that chemical pollution downgrades the quality of the atmosphere or of the water.

Second, moral economy is both weak and powerful. Weak because, as it is often said, morality is a soft power when confronted with hard economic or political issues. Furthermore, the feeling of moral deprivation may lead to apathy rather than to political strength, nationalistic and narrow-minded approaches rather than innovative ones. Powerful, because, when connected to political forces, moral issues may become a lever to foster political change. The European Parliament's recent decision to cap bonuses in the financial industry is a recent and clear example of this power.

\section{References}

Bertrand, M. and Mullainathan, S. (2001) 'Are CEOs Rewarded for Luck? The One without Principals Are', Quarterly Journal of Economics, 116, 901-932.

Durkheim, É. (1976 [1897]) Le suicide. Essai de sociologie, Paris, Presses universitaires de France.

Forsé, M. and Galland, O. (eds) (2011) Les Français face aux inégalités et à la justice sociale, Paris, Armand Colin.

Gabaix, X. and Landier, A. (2008) 'Why Has CEO Pay Increased So Much?', Quarterly Journal of Economics, 123, 49-100.

International Social Survey Programme (ISSP) (1999 survey) www.issp.org

Lazear, E. and Rosen, S. (1981) 'Rank-Order Tournaments as Optimum Labor Contracts', Journal of Political Economy, 89, 841-864. 
Murphy, K. (1999) 'Executives Compensation'. In Aschenfelter, O. and Card, D. (eds) Handbook of Labor Economics, Vol. 3B, New York, NY, Elsevier.

Piketty, T. (2005) 'Top Income Shares in the Long Run: An Overview', Journal of the European Economic Association, 3(2-3), 382-392.

Piketty, T. and Saez, E. (2003) 'Income Inequality in the United States, 1913-1998', Journal of Political Economy, 118(1), 1-41.

Steiner, P. (2011) Les rémunérations obscènes, Paris, La Découverte.

Stiglitz, J. (2012) The Price of Inequality, New York, NY, Norton.

\section{The morality of rescuing banks}

\section{Cornelia Woll*}

Sciences Po, Max Planck Sciences Po Center on Coping with Instability in Market Societies (MaxPo), Paris, France

*Correspondence: cornelia.wol/@sciences-po.fr

Trust in banks is at an all-time low. In most countries touched by the financial crisis, trust in the financial industry experienced a significant drop from 2008 to 2012. According to one recent survey, countries with traditionally high trust in banks, such as the USA, saw confidence fall from 70 to $30 \%$. In countries such as Ireland, trust in banks reached a record low of 6\% (Edelmann Trust Barometer, 2012). ${ }^{1}$

Moral judgments about the role of banks in the financial crisis are close to unanimous. Banks are the culprits of the crisis, brought about by excessive risk-taking and expansion for over a decade. The benefits of these risks constituted private gains. When things turned sour, excessive risks should have been shouldered by those who had benefited. In the worst case, financial institutions should go bankrupt - the ultimate price to pay for unsound strategic choices.

For the most part, this did not happen. Instead, governments everywhere rushed to support their banking sectors, committing considerable amounts of public money to ensure their stability. The categories used to describe these bank bailouts are unambiguous: criticizing the privatization of profits and the socialization of losses, Joseph Stiglitz has called the US bank bailout the 'robbery of the American people' (Fenton and Kan, 2009). Others have commented that 'capitalism without financial failure is not capitalism at all, but a kind of socialism for the rich' (Grant, 2007).

\footnotetext{
${ }^{1}$ The Edelman Trust Barometer is a non-representative online survey. For a representative survey on trust that covers only Europe, see the Eurobarometer surveys.
} 
One of the core concepts in economics describes why government intervention to save the banking sector is a bad thing: it creates moral hazard. The normative valence is signaled by the term itself. It encapsulates the idea that misplaced incentives lead self-interested individuals to rely on others for their own benefit, to 'freeride' on public insurance.

Focusing on moral hazard has led many economists to criticize the bank rescue schemes in very strong terms. In an unusual alliance, they are joined by those opposed to market integration and finance more generally, who also vividly criticize bank support as an undue gift to the banking industry, another proof of the political power of a small fraction of the economy, which has risen to dominate both society and politics. It is difficult not to agree with many of the accusations and hard to understand how anybody could defend committing public money to save the financial industry in times of crisis.

Indeed, those making arguments in support of the bank bailouts do this without any moral high-ground. They underline the fact that the financial industry has become too connected and that the failure of one institution will risk damaging others, in many cases so severely that the entire sector and possibly the economy as a whole will suffer substantially. Rescuing banks is not done for their own sake but to avoid a situation that would be even worse and more costly, where the government would have to step in to ensure that firms and employees in the so-called real economy can continue having access to credit and working. Bailouts are thus simply lesser evils, but by no means desirable or sustainable.

The difficulties that come with this weak moral standpoint were felt by politicians everywhere. All governments in power at the outbreak of the banking crisis have been voted out of office. Stabilizing the economy and following the moral high ground appeared to have been in stark opposition. As the current US Treasury Secretary Timothy Geither puts it: 'Old Testament justice would have prevented us from putting out the panic, getting growth back, making people feel more confident in the future.' As a result, he concludes 'we saved the economy, but we lost the public doing it' (cited in Swedberg, 2012, footnote 14). In many countries where bank bailouts imposed considerable costs on society, there is a sense of a deeply dysfunctional system of political representation and elite dominance.

At the heart of the problem is a disconnect between moral categories, which apply to individual banks, enshrined in the notion of moral hazard, and public justifications for bank rescues, which center on a collective problem: systemic risk. Put differently, the identified moral problem-the behavior of individual banks - and the cited justification for government action - the stability of the financial sector-focus on different units of analysis and therefore inevitably create a tension. Politically, this can only be resolved if the diagnosis of the stakes and our moral categories are aligned. This means that we need to think about the collective moral responsibilities of the financial industry. 
Many governments have attempted to impose such collective responsibilities on the financial industry during the bailout discussions in the fall of 2008. In the weekend negotiations over the fall of Lehman Brothers, the US government assembled the CEOs of the major financial institutions and asked them to come up with a private sector solution, insisting with reference to the support given to Bear Stearns that 'we have done the last one, you are doing this one (Wessel 2010, 16).' The German government repeatedly asked the heads of the major banking associations and the principal financial institutions to put together a collective support mechanism for struggling banks. In France, Denmark and Austria, government and financial representatives worked toward a private sector solution with public backing to ensure continued liquidity.

In most cases, however, the collective support schemes failed to materialize. One leader of the American financial industry responded incredulously: 'we are responsible for our own balance sheets, and now we need to be responsible for others?' (cited in Paulson, 2011, p. 198). The size of the aid needed went far beyond what individual banks were able to support, given that they all had similar difficulties at the time. Even in countries where the financial industry contributed collectively, such as France, Denmark or Austria, the government needed to step in and complement this action through guarantees and additional measures. When collective action of the financial industry did not come about, the government stepped in to pick up the bill. In most cases, collective action from the financial industry failed, and this explains the disproportionate part of the costs born by taxpayers. This failure of collective solutions, however, is much less discussed than the incentive structures that had led to risky behavior of individual banks prior to the crisis.

The implication of my diagnosis for the future of bank regulation and support schemes is that we need more, rather than less, political involvement of the financial industry. This is a rather surprising conclusion, since a chorus of critics have warned that finance has undue political influence. I argue that financial institutions have held many strong individual ties with their governments, but insufficient ties with each other in most countries. In his latest book, American sociologist Mark Mizruchi (2013) analyzes this from a network perspective for the US corporate elite more generally in his latest book. Showing how corporate leaders have succeeded in pushing back constraints imposed by labor and government, while simultaneously being exposed to an ever more short-termist shareholder capitalism, Mizruchi argues that the American business elite today is fragmented and no longer seeks to contribute to social and political issues as they have in the past. Accelerated by the decline of commercial banks, whose boardrooms served as meeting places for the American company networks, business elites have abandoned long-term political initiatives and now concentrate on the short-term interests of their own firms.

During the crisis management in 2008, the great majority of financial elites defended a similar position: unwilling or unable to engage in industry-wide commitments, they 
insisted on their firms' interests only. Given the structural dependence public authorities have on finance, this inaction was an invisible way of exerting power (Woll, forthcoming). In cases where the political authority faces systemic risks, the winning strategy for the financial industry could be called: 'staying divided to conquer.'

Analyzing inaction in terms of power, as I have done here, is in itself a political exercise. It implies that a viable alternative existed or should have been probed (Guzzini, 2005). In doing so, I try to outline what moral debate has not yet taken place, because the political space was occupied with moral hazard considerations and the reprimanding of public authorities accused of being captured by the financial industry. It leaves in the dark the collective responsibilities of the industries in the moment of crisis.

Financial regulation to prevent a future crisis should not only concentrate on moral hazard issues and the incentive structures for individual institutions, which is very usefully done through discussion about bail-in mechanisms and the nature of resolution regimes for failing banks. It also needs to acknowledge the systemic nature of collective interdependence and build privately financed mechanisms to respond to a downturn collectively. A bank levy funding a collective insurance scheme is one way forward and needs to be complemented by mutual surveillance mechanisms between financial institutions that curb free-riding.

During the last 20 years, all of the nearly 100 banking crises that have occurred internationally were resolved through bailouts at the taxpayer's expense. Rather than simply declaring bailouts as the moral failure of banks and later politicians, we should draw the lessons from these experiences and work toward public arrangements that constrain financial institutions to contribute to their own rescue. This can only be done prior to a crisis and implies that we translate the benefits they reap from interdependence into public obligations to protect against system risk. We need to build regulatory arrangements that engage the financial industry as a collective, where their enlightened self-interest can direct them toward maintaining the stability of the economy.

\section{References}

Edelmann Trust Barometer (2012) 'Annual Global Study', New York, NY, accessed at www. edelman.com/trust Accessed November 20, 2012.

Fenton, S. and Kan, D. (2009, March 24) 'Geithner Plan Will Rob American Taxpayer Says Stiglitz', Reuters, accessed at www.reuters.com/article/2009/03/24/us-financialbailout-stiglitz-interview-idUSTRE52N1IO20090324.

Grant, J. (2007, August 26) 'The Fed's Subprime Solution', The New York Times, accessed at www.nytimes.com/2007/08/26/opinion/26grant.html.

Guzzini, S. (2005) 'The Concept of Power: A Constructivist Analysis', Millennium-Journal of International Studies, 33, 495-521.

\footnotetext{
${ }^{2}$ I thank Daniel Mügge for this formulation.
} 
Mizruchi, M. (2013) The Fracturing of the Corporate Elite, Cambridge, MA, Harvard University Press.

Paulson, H. M. (2011) On the Brink: Inside the Race to Stop the Collapse of the Global Financial System, New York, NY, Business Plus.

Swedberg, R. (2012) 'The Financial Crisis in the US 2008-2009: Losing and Restoring Confidence', Socio-Economic Review, Early View, accessed at http://ser.oxfordjournals.org/ content/early/2012/11/01/ser.mws022.full.pdf+html.

Wessel, D. (2010) In FED we trust. Ben Bernanke's War on the Great Panic, New York, NY, Crown Business.

Woll, C. (forthcoming). The Power of Collective Inaction: Bank Bailouts in Comparison, Ithaca, NY, Cornell University Press.

\section{The construction of a moral duty for the Greek people to repay their national $\mathrm{debt}^{\dagger}$}

\section{Wolfgang Streeck ${ }^{*}$}

Max-Planck-Institut für Gesellschaftsforschung, Cologne, Germany

*Correspondence: ws@mpifg.de

Debt must be repaid in full, as a moral principle in everyday life. I owe my neighbor who has helped me out not to let him down. Today public discourse in Europe applies the duty to repay to entire nations, conceived as moral communities: 'Greece' must repay 'its' debt, even though most Greeks have never seen an investment bank from the inside.

The reason why Greek citizens are supposed to be responsible for the debt incurred by their governments and their central bank is that their country is, allegedly, a democracy. 'No taxation without representation' is reinterpreted to mean: 'With representation, full liability'. Greek citizens are made liable regardless of whether they have voted for the governments that have indebted them, or whether they have voted at all or whether they have ever benefited from the debt. Such is the magic of representative democracy.

Remarkably, selecting the Greek citizens who are to be made to pay for 'Greece's' collective debt is left to a government run by the very same parties that have piled up

${ }^{\dagger}$ Dedicated to Emile Durkheim, the sociologist, who has taught us the difference between just and unjust contracts, and to David Graeber, the anarchist, for reminding us of the social meaning of credit and debt. 
the debt in the first place. ${ }^{1}$ Given the size of the debt, the ministers and central bankers that have incurred it cannot possibly repay it personally, comfortable as their salaries, savings and inherited wealth may be. ${ }^{2}$ To the extent that they still hold public office, they have the privilege to declare repayment the moral duty of the pensioners, the patients, the civil servants and the workers of Greece, who are called upon to help out their country by helping out its creditors. ${ }^{3}$

However, neither the capital market nor international politics are a traditional Chinese family, with its unquestionable moral duty for a nephew to repay a loan from his uncle in full, at whatever cost. The morality of a financial market, just as that of international relations, is based on difference, not on identity, and it is therefore regulated by law rather than paternal authority.

In commercial life, a debtor who has become insolvent may initiate legal proceedings to have his debt 'restructured', or even canceled. Liability is often limited to capital invested, protecting private wealth. Creditors are expected to make themselves knowledgeable about the risk of a debtor being unable to service his debt, and adjust the rate of interest they demand accordingly (i.e. ask for an adequate 'risk premium' under the principle of caveat emptor). It is said that, in the USA, having gone bankrupt once or twice is nothing to be ashamed of as it indicates a spirit of daring entrepreneurship.

In most civil law systems, there is a limit to the seizure of property or income to repay outstanding debt, ensuring that private bankruptcy does not result in abject poverty. In Germany, for example, citizens who go bankrupt are allowed to keep roughly 2000 euros a month of their income, to enable them to fulfill family obligations and continue to participate in social life. Courts cannot impound a person's television set, and debtors must remain able to pay for health care and even set aside savings for their old age.

\footnotetext{
${ }^{1}$ From 1989 on, the two major political parties, Nea Demokratia and PASOK, have taken turns in the Greek prime minister's office. The present prime minister, Antonis Samaras (in office since June, 2012), is the leader of Nea Demokratia and governs in a grand coalition with PASOK. In 1989 he was Minister of Finance; in the 1990s he served as Minister for Foreign Affairs.

${ }^{2}$ Not to mention their kleptocratic wealth. See The New York Times, January 5, 2013, on the former Greek finance minister, Papaconstantinou, and his family, among them a cousin who runs, of all things, the country's privatization agency.

${ }^{3}$ And help they did. Gross household disposable income declined on average by $13 \%$ from 2008 to 2011, in which year 30\% of the population of Greece were at risk of poverty (Directorate-General for Employment, 2012). Unemployment, meanwhile, approached 30\% by the end of 2012, and 50\% for young people. By June 2012, salaries in the private and public sectors had been cut by up to $50 \%$, and under a deal with the 'Troika', 150000 public sector jobs were to be eliminated within a year's time. On the catastrophic condition of the Greek health care system after years of Troika governance, see The New York Times, December 26, 2011, 'Fiscal Crisis Takes Toll on Greeks', http://www.nytimes. com/2011/12/27/world/europe/greeks-reeling-from-health-care-cutbacks.html?pagewanted=all\&_r=0.
} 
Moreover, purveyors of credit are legally obliged to provide customers with truthful information about the nature of the loans offered by them, in particular their true cost. Creditors who have not been properly advised can sue for damages. There may even be criminal penalties for withholding important information from customers. (Did Greek politicians and central bankers fully inform their fellow citizens on the risks associated with the cheap credit they started taking up in their name upon entry into the Monetary Union?)

Furthermore, under international law, sovereign countries can unilaterally cancel their debt or apply a 'haircut' to their creditors at their discretion. The ability to default at will is an essential element of national sovereignty, and of course providers of credit to governments know this. Behind it is the principle that countries are obligated first to their citizens and only then to other countries or to international organizations and the 'financial markets'. The moral language of the European financial crisis today is designed to repress the memory of this fundamental condition, so that the 'financial industry' and the governments of lender countries can be safe. Banks and economically leading nation-states are together framing the crisis in a way that makes it the moral duty of a state to apply a haircut, should one become necessary, to its citizens rather than its creditors.

Astonishingly, this moral construction is hardly ever questioned, although an alternative story would seem to be readily available. Its starting point would be the co-responsibility of the creditor for the failure of the debtor: the obligation not to make loans to borrowers who will most likely not be able to repay them. In the USA, this obligation is at the center of a vast number of cases making their way through the courts against reckless providers of subprime mortgages. Similar principles may be invoked if a barman keeps serving double whiskies to a customer who is already drunk, and then lets him drive home in his car.

The official version of the Greek national debt morality play must be all the more welcome to Greece's creditors given the history of Greek indebtedness, a history that is much more complex and includes many more villains than the current 'repay thy neighbor' rhetoric suggests:

(1) Before the advent of the euro, Greece, like Spain and Portugal, received considerable amounts of cash every year from the European Union, allegedly to help the country 'develop.' ${ }^{4}$ It is questionable, however, to what extent European aid in fact served that purpose and indeed whether anyone cared about it. What it undoubtedly did was to stabilize the western European orientation of Greek political elites, rewarding them for rejecting both military dictatorship and Eurocommunism in the 1970s and 1980s. The 'clientelism' of the two main Greek

\footnotetext{
${ }^{4}$ Between 1995 and 1998, Greece received yearly subsidies from the European Union that amounted to roughly $4 \%$ of its gross domestic product.
} 
political parties in the last two decades of the twentieth century was to an important extent funded by European regional and structural development funds.

(2) Cash transfers to Greece (and to Spain and Portugal as well) were frozen in the late 1990s, in the course of efforts in the rich countries to consolidate their public finances, as well as in response to the need to extend financial assistance to eastern Europe after the end of communism. Admission to the Monetary Union had the welcome side effect that it enabled Mediterranean countries to borrow money in international financial markets at roughly western European rates, replacing transfers from national treasuries with credit from international banks. In effect, this was the international equivalent of the 'privatized Keynesianism' (Crouch, 2009) of the time in the domestic political economies of countries like the USA and the UK.

(3) The European Union was acutely aware of the need to give Greece and the other Mediterranean countries access to cheap credit in lieu of fiscal transfers. As Monetary Union started, the Commission - in the person of the Commissioner in charge of financial services, Mario Monti-ruled that public debt from member states could indistinctly be used by banks as collateral for loan transactions (Gabor and Ban, 2012). This caused a run on state papers and led to rapid convergence of risk premiums among EMU countries. It enabled Greece in particular to indebt itself at a previously unknown pace, without its interest payments skyrocketing (Figure $1^{5}$ ).

(4) The need for Greece to take up credit resulted not least from its truly byzantine tax regime. The media like to point to widespread tax evasion among the working and middle classes, which fits in with the rhetoric holding them morally responsible for paying off the national debt on behalf of Greece as a whole. It is remarkable, however, that the European Union never tried to make Greece rescind the constitutional tax privileges of the Orthodox Church $^{6}$ or of Greek shipowners. ${ }^{7}$ Nor did the European Commission object

\footnotetext{
${ }^{5}$ The two vertical bars indicate the years of Greece's entry in EMU and the onset of the Great Recession, respectively. The right-hand axis measures government debt in percent of GDP; all other variables are measured by the left-hand axis.

${ }^{6}$ See The Guardian Weekly, October 4, 2011: 'The Greek church and its monasteries will not have to pay the deeply unpopular property tax that the government introduced in September in an effort to fulfill Greece's austerity targets. "The church will be taxed on any assets used for business purposes," a finance ministry spokesman said after news of the tax caused an outcry. Places of worship and charitable organizations will be exempt from the tax. But the borderline is fuzzy and the accounts of the Orthodox church are opaque.... For details see http://www.guardian.co.uk/world/2011/oct/ 04/greece-orthodox-church-economic-crisis.

${ }^{7}$ See Ekathimerini, June 12, 2012: 'Greek ship owners who remitted more than $\$ 175$ billion in untaxed earnings to the country in 10 years say they would relocate the businesses if a new government scraps the fiscal exemption, risking as many as 60,000 jobs. The country's estimated 762 vessel owners pay no tax on
} 


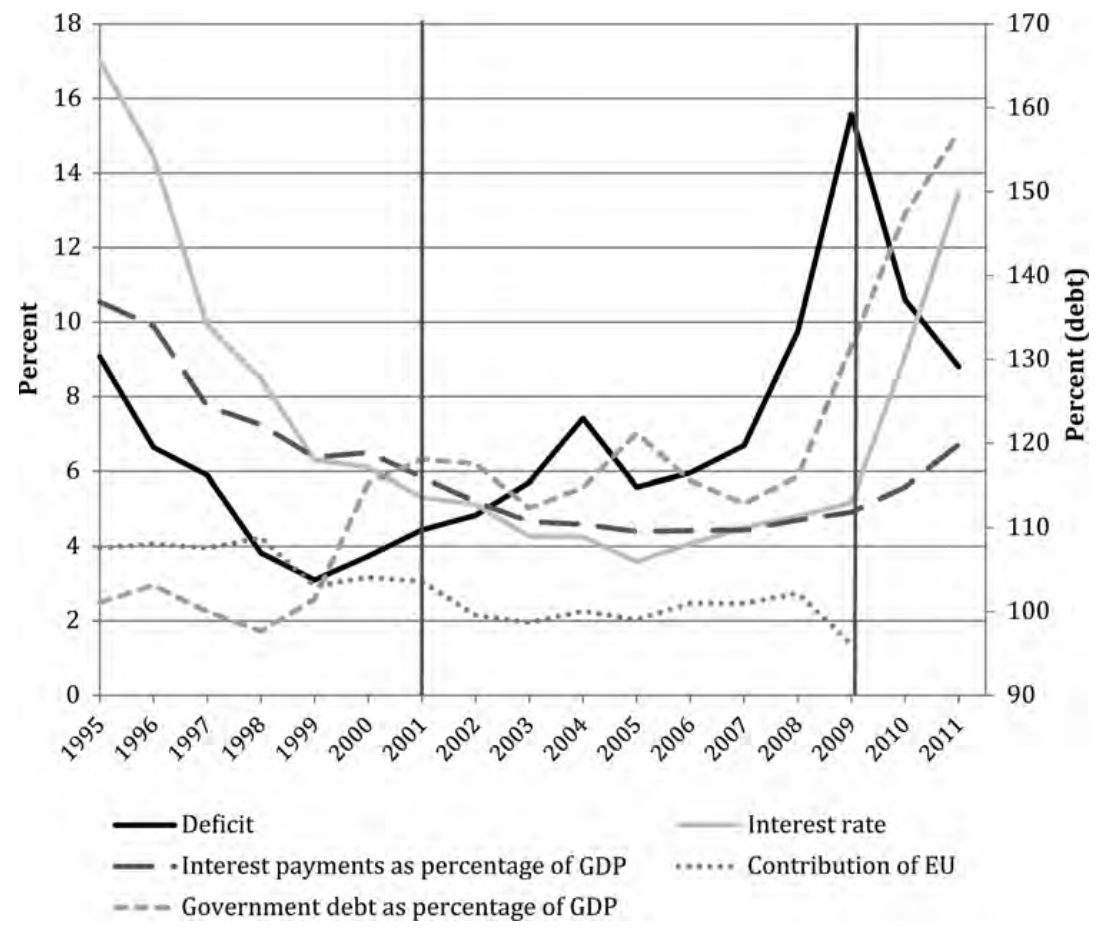

Figure 1 Greece: Monetary Union and public finance.

Source: EU-Haushalt Finanzberichte, OECD National Accounts, OECD Economic Outlook Database.

when Greece, immediately upon its admission to EMU, cut the top rate of its corporate tax from 40 to $20 \%$ (Markantonatu, 2012), replacing revenue foregone with cheap credit. ${ }^{8}$ Tax competition is deeply written into the fabric of the Single Market and the European Union generally; it is considered economically healthy especially for the higher taxation countries in the North and West whose tax regimes are in this way put under pressure.

(5) In order for Greece to formally meet the criteria of admission to EMU, it had to engage in creative accounting, for which it needed the assistance of that

international earnings brought into Greece under rules incorporated in the country's constitution since 1967. The SYRIZA party, which opposes Greece's international bailout and is shown by polls as vying for first place before a June 17 election, says it wants to abolish the tax break.' http://www.ekathimerini .com/4dcgi/_w_articles_wsite2_1_12/06/2012_446527. The 1967 constitution was imposed by the military dictatorship. In 1972 the dictator, General Papadopoulos, was made Lifetime Honorary President of the Greek Ship-owners Association (Markantonatu, 2012).

${ }^{8}$ Both transfers from EU structural funds and low-interest loans after Monetary Union may reasonably be described as subsidies by western European countries for an oligarchic tax regime in an effort to secure social peace on their Mediterranean glacis, by sparing a country like Greece from the need to revolutionize an archaic social structure. 
bank-of-all-banks, Goldman Sachs. It is now known that Goldman made an extraordinary profit on that operation. ${ }^{9}$ It is not yet known enough, however, that the president of the Greek central bank at this time was one Lukas Papademos, who a few years later advanced to the position of vice president of the ECB, and from there to that of the prime minister of Greece, appointed by international capital markets to secure the repayment of Greek's debt to its creditors. Nor is it sufficiently known that when Greece's entry in EMU was made possible, Mario Draghi was waiting in the wings to become the European chief of Goldman Sachs. Thereafter, in rapid succession, he became the governor of the Banca d'Italia — which includes membership in the governing body of the ECB — and then the president of the ECB. It is completely inconceivable that Papademos and Draghi and their ilk should not have been aware of the way in which the Greek government of the time made use of their country's membership in EMU to replace both domestic taxes and international fiscal subsidies with cheap credit from, among others, Goldman Sachs.

(6) Another aspect of the Greek tragedy is the fact that rampant capital flight from Greece remained and remains entirely unchecked at both the national and the European level. Newspapers have again and again written about the vast amounts of Greek money that are flowing into the real estate markets of cities such as London, ${ }^{10}$ Paris and Berlin, greatly benefiting local owners of luxury houses and apartments. This is another result of the lifting of capital controls in the 1990s and thereafter, which was part and parcel of the Internal Market and, in particular, Monetary Union. Never has the European Union or its leading member states suggested to the Greek government that it limit transactions of this sort, nor have they suggested that member governments tax Greek real estate investment abroad as an act of 'European solidarity' (Grözinger, 2012).

\footnotetext{
${ }^{9}$ See Bloomberg, March 6, 2012, 'Goldman Secret Greece Loan Shows Two Sinners as Client Unravels'. The article begins as follows: 'Greece's secret loan from Goldman Sachs Group Inc. (GS) was a costly mistake from the start. On the day the 2001 deal was struck, the government owed the bank about 600 million euros (\$793 million) more than the 2.8 billion euros it borrowed, said Spyros Papanikolaou, who took over the country's debt-management agency in 2005. By then, the price of the transaction, a derivative that disguised the loan and that Goldman Sachs persuaded Greece not to test with competitors, had almost doubled to 5.1 billion euros ... '

${ }^{10}$ See The Guardian, April 13, 2010: 'Greeks taking fright at the fiscal crisis [ ... ] are snapping up properties in Britain as part of a desperate flight of capital. [ ... ] Prime real estate in London, the traditional home of Greece's wealthy shipping community, is being bought at an unprecedented rate by rich Greeks desperate to transfer their bank deposits. The land grab has astounded estate agents, with many referring to the new homebuyers as "cash Greeks" because of their willingness to part with large sums of money in record time to secure $£ 1 \mathrm{~m}$-plus properties. "They are all cash buyers, serious players who are only interested in the high-end market around Regent's Park, Mayfair and Marylebone," said Panos Koutsoyiannakis at the central London estate agents Fraser \& Co.' http:// www.guardian.co.uk/business/2010/apr/13/greek-debt-crisis-capital-outflow.
} 
The moral discourse on Greek public finances focuses on 'the Greek citizens' and their presumed duty to pay off debt taken up by their past governments, supposedly to enable their voters to enjoy an easy life on unearned income. It aims primarily at pensioners and workers, in both the private and the public sectors, and functions as a deplorably successful ideological tool wielded by the 'market forces' and their bureaucratic-political running dogs, in Greece as well as in Brussels and Washington. The aim is to suck the Greek people dry and strip them of everything they may have gained for themselves in three decades of democracy. I am convinced that the story does not end here and that Greece is no more than a testing ground for the same treatment to be applied to other European countries. The personnel to perform the sucking are already in place while the instruments are being continuously refined in the Greek operating theater.

\section{References}

Crouch, C. (2009) 'Privatised Keynesianism: An Unacknowledged Policy Regime', British Journal of Politics and International Relations, 11, 382-399.

Directorate-General for Employment, Social Affairs and Inclusion (2012) Employment and Social Developments in Europe 2012, Brussels, European Commission.

Gabor, D. and Ban, C. (2012) 'Fiscal policy in (European) hard times: financialization and varieties of capitalism', Conference Paper, Rethinking Financial Markets, World Economics Association (WEA), November 1-30, 2012.

Grözinger, H. (2012) 'Griechenland: Von den Amerikas lernen, heißt siegen lernen', Blätter für deutsche und internationale Politik, 9, 35-39.

Markantonatu, M. (2012) The Uneasy Course of Democratic Capitalism in Greece: Regulation Modes and Crises from the Post-War Period to the Memoranda, unpublished manuscript, Köln, Max-Planck-Institut für Gesellschaftsforschung.

\section{The economy as morality play, and implications for the Eurozone crisis}

\section{Marion Fourcade ${ }^{*}$}

University of California, Berkeley, CA, USA;

Sciences Po, Max Planck-Sciences Po Center on Coping with Instability in Market Societies (MaxPo), Paris, France

*Correspondence: fourcade@berkeley.edu

The economy is always and everywhere the theater of a morality play, where moral worth is being negotiated alongside economic worth. People interpret differential rewards in the economy both as a 'functional requirement' and as a 'normative 
imperative' flowing from equity considerations: those who put in more work should be better compensated (Sachweh, 2012). Even when routinely contradicted by the reality of social inequalities, this moral belief is so strong that those who find themselves at the bottom of the economic scale, or in a situation of financial distress, are often suspected of low effort, innate mediocrity or moral weakness. Always in want of money, but never trusted with it, the poor in particular are the object of enormous suspicion, which seems to justify special controls and obligations. ${ }^{1}$ Moral hierarchies are brought into alignment with economic hierarchies through the frequent and ordinary 'shaming of those who fail' (Sayer, 2005, p. 959): big and small acts of contempt, obliviousness, condescension, disrespect and coercion waged in everyday life as well as through the operation of institutions that deploy considerable resources and ingenuity to tell the 'deserving' apart from the 'undeserving.'

Conversely, the position of the economically powerful is, at least partly, naturalized as the outcome of merit, talent or moral strength. Further symbolic qualification may come in the form of self-confidence, bodily appearance and hexis, linguistic and social skills, and cultural capital. Embodied dispositions and attributes operate as implicit resources that anchor social hierarchies and make them more legitimate-not only in the eyes of the dominant, but in those of the dominated as well. This is, quite simply, what Pierre Bourdieu (1984) called symbolic violence. To be sure, rich individuals may elicit animosity and contempt, too, particularly when they are perceived as haughty and distant (e.g. see Prasad et al., 2009), or abusing their power, or having inherited-rather than earned-their wealth (Beckert, 2008). But the asymmetry remains: the social psychology literature has documented, time and again, that even young children learn early on to make much more positive attributions about the 'moral character' of the rich versus the poor (Skafte, 1989).

\section{Hierarchy and debt}

Economic transactions and interactions are a powerful vehicle for the crystallization of moral categories precisely because they are a key mechanism through which individuals and human collectives obtain or are recognized positions in the social structure. But nowhere is the entanglement between social position, economic worth and moral worth more obvious than in the case of debt, where the

\footnotetext{
${ }^{1}$ Piven and Cloward (1971), for instance, have described the insidious surveillance strategies developed by welfare officials to make sure recipients of public assistance programs really deserved help.

${ }^{2}$ Much research suggests that the cultural boundary between the 'deserving' and the 'undeserving' is strengthened through racial or ethnic stigmatization. Thus the weakness of solidaristic feelings and institutions in the USA has often been related to the country's brutal racial history, which has resulted in the seemingly intractable situation of a large black underclass (Quadagno, 1996; Gilens 1999; Lamont, 2000). In Europe, weakening support for the welfare state has also been understood as a byproduct of negative attitudes toward immigrants (Senik et al., 2009; Eger, 2010).
} 
economic standing and character of borrowers are simultaneously constituted as the precondition of the economic relationship and as its essential stake. Thus Max Weber (1978) saw the distinction between debtors and creditors as a primordial principle of social differentiation and a point of origin for the constitution of 'economic classes': that distinction structured society into groups with unequal economic trajectories. But it also differentiated between people of unequal moral worth. To be sure, lending was always a morally suspicious business, and it was stigmatized accordingly throughout history. In a fully developed credit economy, where lenders are large and impersonal, however, the moral burden of the relationship falls disproportionately on the shoulders of the borrower. As David Graeber (2010, 120) puts it,

During the time that the debt remains unpaid, the logic of hierarchy takes hold. ... But always there is the assumption that the situation is somewhat unnatural, because the debt really ought to be paid. This is what makes situations of effectively unpayable debt so difficult and painful. Since creditor and debtor are ultimately equals, if the debtor cannot do what it takes to restore herself to equality, there is obviously something wrong with her.

And thus a bad debtor will be punished through the very instruments of her sin: having lost her 'credit', she will find that money is more expensive now, or more difficult to obtain altogether.

Just like there is an economic and moral ordering among people, there is an economic and moral ordering among nation-states. Debt stands at the core of it, too. Insisting that money is owed-in the form of tributes, reparations and the fulfillment of contractual obligations - is how political entities have historically asserted their superiority against vulnerable others, be they defeated enemies, rebellious colonies, or simply weaker economic partners.

\section{Tough love}

Since the widespread institutionalization of sovereign (government) debt in the 1800s, the economic position of political entities known as states is translated through the conditions this debt faces on international financial markets. The price of a country's sovereign debt (the interest rates its bonds command on these markets) appears as an objectified measure of some sort of underlying moral worth in the eyes of investors, encapsulating the country's ability and willingness to repay. Because these evaluations are both hard to pin down and highly speculative, however, variations in the terms of credit faced by states may be extremely brutal, driven by rapid swings in collective sentiment as much as by changes in fundamentals (see, for instance, the 2009 un-hinging of interest rates 
on Greek debt in Wolfgang Streeck's article in this symposium). Thus nations may find themselves in the situation of being all but priced out of private financing (in other words, the risk premium is so high that they cannot borrow anymore). This is when the institutions of last resort intervene, the International Monetary Fund first among them; with the crisis in the Eurozone, the European Union and the European Central Bank have also stepped in. But with such interventions the nature of the moral regulation changes. Instead of the mechanical disciplining of the market (in the form of country credit ratings, the up and down movements of the interest rate on sovereign debt bonds and the price of insurance for these bonds-or sovereign credit default swaps), an alternative arsenal may now be rolled out in exchange for affordable credit, with conditionality and surveillance at its core. As The Guardian recently phrased it, 'you could think of the IMF as a global payday loan company for countries who have got into trouble and can't meet their financial commitments - the difference being that instead of charging sky-high interest rates, it demands radical economic reforms' (Aitkenhead, 2012).

The analogy between individuals and nations is tricky, however. First, countries technically have the capacity to tax their population, so government debt, unlike individual debt, is supposedly much less risky. [This, however, is mitigated by the fact that countries default on their debt all the time, and have been doing so for over two centuries (Reinhart and Rogoff, 2009).] Second, the rating process is opaque, shrouded in mystery and behind-the-scenes politics: against the mechanical objectivity of technologies of individual credit (especially scoring), country ratings come in the form of much less precise categorical statements-letter grades rather than numerical scores. Third, it is materially straightforward to hold individuals accountable for debts they have contracted. But the moral responsibility of a country's political leaders, let alone its banks, is not easily fungible into the moral responsibility of its citizenry. So the lenders of last resort are faced with a moral dilemma: politicizing blame (by targeting governments or private entities) or nationalizing it (by encompassing national communities). Often, the line between the two is very hard to tread.

The conditional 'helping hand' of the IMF interacts with political entities with a mix of coercion and training ['tough love' in the words of Christine Lagarde, the current head of the institution]. As such it is a deeply corrective mechanism, with inescapable moral effects. Aimed at governments, programs have an unmistakable civilizational purpose-conditionality is a cultural, inherently modernist, project to train, educate and profoundly reform those societies whose poor performance has exposed as inadequate, insufficient, incompetent and shackled by outdated institutions inimical to the flourishing of modern capitalism. Experts, including from our own ranks, have their own vocabulary to designate the typical flaws: rampant 'corruption', low 'state capacity', poor 'governance', 'rigidities' of all sorts and 'inefficient' policies. The more troubled the country, the longer the road to travel, and the tougher the conditions: in part this is because conditionality 
is the translation, in economic terms, of a perceived civilizational distance as well as, certainly, of a real power distance.

There is no escaping the collective nature of this form of discipline. A country's fall out of favor on international markets is a profoundly meaningful event in its citizens' lives. And this is not simply because nearly everyone's material situation is affected by its ramifications. To be sure, people are being economically downgraded: if the currency is devalued standards of living will sink instantly; even in the absence of a devaluation, the lost margin of maneuver in the face of high borrowing costs and the stringent demands of the 'helping hands' on the fiscal front will force many states into austerity, as has been the case in Portugal, Ireland, Greece and Spain. Thus the intermediary classes in southern Europe, which were the big beneficiaries of the short-lived moment of economic convergence, cosmopolitanism and Euro-optimism before 2008, have suddenly found themselves thrown back in time-not only to bleaker economic perspectives, but also back to the confines of their nationality and its supposed backwardness.

\section{Spoiled identities}

But there are other consequences. As the perspective of convergence across Eurozone economies recedes on both the financial and the real economy fronts, ${ }^{3}$ it has been replaced by the notion of an unbridgeable cultural gap between the North and the South, which is skillfully exploited by Euroskeptics of all stripes. So the economically vulnerable also face a form of moral downgrading, which may take different forms. First, through the fusion and confusion of economic moralities between the individual and collective levels, the average citizen of the forsaken countries is emblematically represented, in the critics' discourse, as a fool; a tax evader; an imprudent borrower; or a freeloader enabled by a much too lavish state. The moral violence of such symbolic markers leaves no one undisturbed, and thus stigmatized citizens will emphatically deny them; resent them; and sometimes own up to them in an anxious search for absolution.

Second, the crisis-ridden countries of the Eurozone have found themselves lumped collectively into one general flawed category. This moral sinkhole absorbs and blends them together, ${ }^{4}$ in spite of the fact that they may have very different crisis etiologies. Southern European countries, for instance, were nicknamed PIGS (for Portugal, Italy, Greece Spain) in the UK press in 2007. (They were the 'club med' countries before that.) In 2008 the epithet was made more shrillsounding with the addition of another I for Ireland-PIIGS. This amalgamation may, in some cases, relieve the moral burden of individual countries by mutualizing

\footnotetext{
${ }^{3}$ See, e.g., Atkins (2012).

${ }^{4}$ See Eyal (2010) for the concept of 'moral blender'.
} 
it: thus a citizen from Greece might find some comfort in thinking 'we're not the only ones'. But this kind of commonality is not necessarily reciprocated, or valued across the board, so solidarity has not really emerged within southern Europe. Mostly, the moral sinkhole has fueled centrifugal tendencies as people and governments have been striving to distance themselves from those in countries not (really) like them. Spain's desperate efforts to avoid a European stability mechanism/IMF program is all about avoiding the stigma of being lumped together in the same category as Greece.

Third, unlike the many nations, such as Argentina, that have been externally disciplined in the past, the Eurozone morality play has been performed by democratically elected governments with the backing, if not the active encouragement, of a large segment of their populations. Individuals and politicians in the morally downgraded countries have to see themselves through the looking glass of a collective, pan-European (by and large a pan-northern European) stigma of incapacity and illegitimacy_not through the esoteric pronouncements of a remote and widely unpopular institution (the IMF). This is real, intersubjective stigma elevated to the international stage. Their identity spoiled, contrite elites and populations are expected to 'manage' it properly, which in the sociology of Erving Goffman (1963) essentially means that they have to quietly 'accept' the implicitly inferior status ascribed to them.

\section{Moral struggles}

In the Portuguese and Irish cases, a silent form of heroic self-constraint has indeed prevailed, where each country has voluntarily engaged in a desperate, and very costly, race for economic virtue (so far: opposition to this strategy is mounting fast at the time of this writing, particularly in Portugal). ${ }^{5}$ In the Greek case, however, the process has been much more brutal, externally driven and infantilizing, perhaps because the moral violation (the cooked national books, the tax evasion) was perceived to be more egregious in the first place. As a result, the divides between the nation and its outside, between the complying government and the defiant population, between the taxed and the untaxed, between public and private employees have been thrown into sharp relief, with each side projecting the moral responsibility for the fiscal mess onto the other. And thus rebellion and civic strife have set in. ${ }^{6}$

\footnotetext{
${ }^{5}$ The same painful processes even extend outside the Eurozone, for instance, in would-be member Latvia, deeply anxious to avoid falling back into the Russian orbit, and eager to demonstrate its European moral worthiness by tightening its belt.

${ }^{6}$ Italy, likewise, was mostly defiant—and barely governable—with populist movements riding on a wave of anti-German sentiment.
} 
As the recent creation of an anti-Euro party in Germany attests, the dominant countries are not left untouched by these centrifugal forces: they, too, split over the possibility of greater pan-European solidarity, all the more since they are the main targets of public resentment by those populations on the losing side of the Eurozone. Perhaps the question of whether the cures proposed are economically effective or normatively justifiable is beyond the reach of this short piece. But pointing out the political importance of the moral-economic mechanics at work is not. These exhausting struggles provoke and nourish deep emotions, fuel nationalistic feelings and heighten boundaries with the outside, especially where foreign advisers and managers step in. These sentiments are hardened by the preexisting nature of national or regional bonds, and they revive long, and ugly, histories of international relations. These revivals have already brought about reverse moral struggles, from Greece toward Germany in particular, over debts long forgiven and moral obligations inherited from a time Europe had worked so hard to burry and forget.

The energy generated by these emotions and the social devastation that has accompanied the crisis management process so far have also driven attempts to assert or reclaim the high moral ground - through politics, mainly, of a more peaceful or more violent sort. These attempts include the rise of xenophobia, centrifugal forces brewing in Spain and Belgium and strong resistance to expanding the European federalist project into fiscal territory. The possible implosion of some states under the pressure of economic austerity raises the specter of a Europe of the pick-and-choosers, just the opposite of the great hopes that had nourished the European project at its birth. And the sacrifice of large and young fractions of the population on the altar of the moral responsibility to repay a debt most of them did not contract tragically feeds into a political radicalization that may estrange them further from the targets of their resentment.

These moral struggles and the different paths they inspire are not a distraction from some 'real' economic issues beneath. They stand at the economy's core and at the heart of the Eurozone's future-and, with it, the future of Europe.

\section{References}

Aitkenhead, D. (2012, May 25) 'Christine Lagarde: Can the Head of the IMF Save the Euro?', The Guardian.

Atkins, R. (2012, September 3) 'Eurozone: Convergence in Reverse', Financial Times. http: //www.ft.com/cms/s/0/c7dfaa26-f59f-11e1-a6bb-00144feabdc0.html\#axzz2VdoegXKK. Accessed June 6, 2013.

Beckert, J. (2008) Inherited Wealth, Princeton, NJ, Princeton University Press.

Bourdieu, P. (1984) Distinction: A Social Critique of the Judgement of Taste, Cambridge, MA, Harvard University Press. 
Eger, M. A. (2010) 'Even in Sweden: The Effect of Immigration on Support for Welfare State Spending', European Sociological Review, 26, 203-217.

Eyal, G. (2010) The Autism Matrix, Cambridge, Polity.

Gilens, M. (1999) Why Americans Hate Welfare: Race, Media and the Politics of Antipoverty Policy, Chicago, IL, University of Chicago Press.

Goffman, E. (1963) Stigma: Notes on the Management of Spoiled Identity, Englewood Cliffs, NJ, Prentice-Hall.

Graeber, D. (2010) Debt: The First 5,000 Years, Brooklyn, NY, Melville House.

Lamont, M. (2000) The Dignity of Working Men: Morality and the Boundaries of Race, Class, and Immigration, Cambridge, MA, Harvard University Press.

Piven, F. F. and Cloward, R.A. (1971) Regulating the Poor: The Functions of Public Relief, New York, Vintage.

Prasad, M., Perrin, A. J., Bezila, K., Hoffman, S. G., Kindleberger, K. and Manturuk, K. (2009) 'The Undeserving Rich: "Moral Values" and the White Working Class', Sociological Forum, 24, 225-253.

Quadagno, J. (1996) The Color of Welfare: How Racism Undermined the War on Poverty: How Racism Undermined the War on Poverty, Oxford and New York, Oxford University Press.

Reinhart, C. M. and Rogoff, K. S. (2009) This Time Is Different: Eight Centuries of Financial Folly, Princeton, NJ, Princeton University Press.

Sachweh, P. (2012) 'The Moral Economy of Inequality: Popular Views on Income Differentiation, Poverty and Wealth', Socio-Economic Review, 10, 419-445.

Sayer, A. (2005) 'Class, Moral Worth and Recognition', Sociology, 39, 947-963.

Senik, C., Stichnoth, H. and Van der Straeten, K. (2009) 'Immigration and Natives' Attitudes towards the Welfare State: Evidence from the European Social Survey', Social Indicators Research, 91, 345-370.

Skafte, D. (1989) 'The Effect of Perceived Wealth and Poverty on Adolescents' Character Judgments', The Journal of Social Psychology, 129, 93-99.

Weber, M. (1978) Economy and Society: An Outline of Interpretive Sociology. Vol. 1, Berkeley, CA, University of California Press. 